\title{
ANALISA KANDUNGAN Pb DAN Fe PADA AIR MINUM DALAM KEMASAN (AMDK) PRODUKSI PANTAI BARAT SELATAN ACEH
}

\author{
Zaulfikar Abbas ${ }^{* 1}$ dan Muhamad Reza ${ }^{2}$ \\ ${ }^{1}$ Jurusan Teknik Industri, Fakultas Teknik, Universitas Teuku Umar \\ ${ }^{2}$ Fakultas Kesehatan Masyarakat, Universitas Teuku Umar \\ E-mail: ${ }^{* 1}$ zaulfik@yahoo.com
}

\begin{abstract}
All minerals contained in drinking water, including $\mathrm{Pb}$ and $\mathrm{Fe}$, shall be in accordance with Regulation of the Minister of Health of the Republic of Indonesia No. 492/MENKES/PER/IV/2010, which shall not exceed $0.01 \mathrm{mg} / \mathrm{l}$ for $\mathrm{Pb}$ and $0.3 \mathrm{mg} / \mathrm{l}$ for Fe. The provision is also required against Bottled Drinking Water (AMDK). If the content is excessive can disrupt and endanger health.

Based on Permenkes Number 492/2010, the researchers have conducted the test of $\mathrm{Pb}$ and Fe content of 7 (seven) brands of Bottled Drinking Water (AMDK) local production of the western-southern coastal area of Aceh province. In the study, researchers used descriptive methods based on laboratory test results. The sampling technique is done by purposive sampling, in which each brand is taken 3 (three) drinking water sample in glass packaging 220-230 ml from different market/location. The results of observation, researchers found 7 brands of Drinking Water In Packaging (AMDK). The test is repeated 2 times. So the total is 42 test samples.

The results showed that from 42 test samples gave excellent results on $\mathrm{Pb}$ content, which of the seven brands of AMDK tested did not show the Pb content to the lowest limit that can be detected by Atomic Absorption Spectrosphotometry (SSA), which is $0.002 \mathrm{mg} / \mathrm{l}$. The content of $\mathrm{Pb}$ is far below the requirement stipulated in Permenkes Number 492/2010, is not exceeding $0.01 \mathrm{mg} / \mathrm{l}$. While the Fe content of the seven brands of AMDK tested gave varying values, but the content is still very low compared to the Fe content permitted Permenkes No. 492/2010, which does not exceed $0.3 \mathrm{mg} / \mathrm{l}$. Where there are 2 brands of AMDK have Fe content ranging from 0.12 to $0.17 \mathrm{mg} / \mathrm{l}$, while from 5 other brands of AMDK have Fe content ranges from 0.0113 to $0.0941 \mathrm{mg} / \mathrm{l}$.

So, from the results obtained it can be concluded that the seven brands of Bottled Drinking Water (AMDK) production area of South West Coast of Aceh is safe for consumption, because it does not cause the impact of $\mathrm{Pb}$ and Fe content is still far from the maximum set Permenkes No. 492/2010.
\end{abstract}

Keywords: $\mathrm{Pb}, \mathrm{Fe}$, Bottled Drinking Water

\section{PENDAHULUAN}

Air merupakan salah satu kebutuhan dasar bagi kehidupan di bumi. Tanpa air, berbagai proses kehidupan tidak dapat berlangsung. Oleh karena itu, ketersediaan air bukan saja kebutuhan utama bagi kelangsungan hidup manusia, akan tetapi ketersediaan air juga sangat menentukan kualitas kesehatan dan derajat kesejahteraan hidup manusia [1]. 
Seiring kebutuhan air yang terus meningkat, terutama untuk konsumsi, telah mendorong munculnya berbagai usaha air minum, baik Air Minum Dalam Kemasan (AMDK) maupun air minum isi ulang. Setiap air minum yang dihasilkan, harus memenuhi syarat kualitas yang ditetapkan oleh Menteri Kesehatan Republik Indonesia, diantaranya kadar mineral. Jika kadar mineral tersebut berlebih maka dapat menganggu kesehatan [2].

Persyaratan air minum sebagaimana ditetapkan dalam Permenkes Nomor 492 Tahun 2010 Tentang Persyaratan Kualitas Air Minum, yaitu :

1. Syarat Fisik, diantaranya tidak berwarna, tidak berasa, tidak berbau, harus jernih suhunya dibawah suhu udara $\left( \pm 25^{\circ} \mathrm{C}\right)$.

2. Syarat Kimia

Air minum ynag baik adalah air minum yang tidak tercemar secara berlebihan oleh zatzat kimia dan mineral yang berbahaya bagi kesehatan. Zat-zat kimia yang dibutuhkan oleh tubuh hendaknya harus terdapat dalam air minum dalam kadar tertentu sesuai syarat kesehatan.

3. Syarat Biologi

Menurut Permenkes Nomor 492 Tahun 2010, air minum tidak boleh mengandung satupun bakteri. Air minum yang telah mengandung bakteri, terutama bakteri coli maka air tersebut dianggap telah terkontaminasi/tercemar.

Selanjutnya, berdasarkan peraturan Direktur Jendral Industri Agro dan Kimia Nomor 29/IAK/per/3/2007 tentang pedoman pengawasan Air Minum Dalam Kemasan (AMDK) di pabrik, dimana Air Minum Dalam Kemasan (AMDK) adalah air baku yang telah diproses, dikemas, dan aman diminum. Air Minum Dalam Kemasan (AMDK) merupakan salah satu produk industri yang SNI-nya telah diberlakukan secara wajib, oleh karena itu pengawasan terhadap perusahaan Air Minum Dalam Kemasan (AMDK) adalah mutlak harus dilakukan [3].

Air Minum Dalam Kemasan (AMDK) memungkin tercemar Pb. Hal ini karena banyak perusahaan Air Minum Dalam Kemasan (AMDK) yang masih mengunakan pipa mengandung timbal $(\mathrm{Pb})$ saat pengambilan air baku, sehingga sangat besar kemungkinan tercemarnya air minum oleh $\mathrm{Pb}$ [4].

Logam $\mathrm{Pb}$ tidak dibutuhkan oleh tubuh manusia, karena jika $\mathrm{Pb}$ terdapat dalam tubuh manusia, $\mathrm{Pb}$ dapat menghambat aktivitas enzim yang terlibat dalam pembentukan hemoglobin $(\mathrm{Hb})$. Disamping itu, sebagian $\mathrm{Pb}$ dapat terikat dengan protein, sedangkan sebagian lain terakumulasi dengan ginjal, hati, kuku, jaringan lemak dan rambut (Widowati dkk, 2008). Selanjutnya Widowati dkk menambahkan bahwa toksisitas $\mathrm{Pb}$ dapat mengakibatkan kelelahan, kelesuan, iritabilitas, gangguan gastrointestinal, kehilangan libido, infertilitas pada laki-laki, gangguan menstruasi serta aborsi spontan, depresi, sakit kepala, sulit konsentrasi, daya ingat terganggu, sulit tidur dan penurunan IQ. Selanjutnya Soemirat (2011) menambahkan bahwa Pb adalah racun sistemik yang dapat menimbulkan gejala seperti; rasa logam dimulut, garis hitam pada gusi, anorxia, muntah-muntah, iritasi, perubahan kepribadian, kelumpuhan, kebutaan, anemia dan albuminuria.

Permasalahan lain pada produksi Air Minum adalah pada proses pengendapan zatzat tersuspensi dalam air baku, yang terkadang memaksa mineral-mineral alami yang berguna bagi kesehatan manusia juga ikut terendapkan. Mineral tersebut diantaranya adalah unsur besi $(\mathrm{Fe})$. Jika Logam timbal $(\mathrm{Pb})$ adalah unsur yang tidak dikehendaki oleh tubuh, lain halnya dengan logam besi $(\mathrm{Fe})$, termasuk salah satu unsur yang sangat diperlukan oleh tubuh, akan tetapi harus dalam jumlah yang sesuai.

Kejadian pendarahan mengakibatkan hilangnya zat besi $(\mathrm{Fe})$ dari tubuh. Kehilangan zat besi lainnya dapat terjadi pada saat menstrubasi wanita subur. Kehilangan zat besi $(\mathrm{Fe})$ tersebut berdampak kepada kekurangan zat besi (Fe). Kekurangan zat besi $(\mathrm{Fe})$ juga dapat menganggu pertumbuhan janin pada wanita hamil. Bila cadangan besi 
dalam tubuh berkurang, dapat terjadi anemia. Kelebihan zat besi $(\mathrm{Fe})$ bisa menyebabkan keracunan, dimana terjadi muntah, diare dan kerusakan usus [2].

Oleh karena itu, kandungan zat-zat (mineral) yang dibutuhkan oleh tubuh manusia pada Air Minum Dalam Kemasan (AMDK) adalah mutlak harus dilakukan dalam jumlah sesuai sebagaimana telah ditetapkan. Adapun kandungan $\mathrm{Pb}$ dalam Peraturan Menteri Kesehatan Nomor 492 Tahun 2010 Tentang Persyaratan Air Minum adalah tidak melebihi $0,01 \mathrm{mg} / \mathrm{l}$ dan kandungan $\mathrm{Fe}$ tidak melebihi $0,3 \mathrm{mg} / \mathrm{l}$. Oleh karena itu, kandungankandungan mineral tersebut harus dilakukan pengujian secara berkala sesuai aturan yang telah ditetapkan agar tidak membahayakan dan mengganggu kesehatan masyarakat.

Pantai Barat Selatan Aceh (BARSELA) pada umumnya adalah wilayah pesisir yang di beberapa tempat sepanjang pantai adalah daerah rendah berawa-rawa. Aceh Jaya, Aceh Barat dan Aceh Singkil adalah kabupaten-kabupaten yang sangat merasakan krisis air bersih akibat topography daerah yang demikian tersebut. Sedangkan Kabupaten Aceh Barat Daya dan Kabupaten Aceh Selatan adalah daerah dengan topography pengunungan dengan hutan yang masih terjaga, sehingga sumber air baku masih tersedia dalam jumlah yang sangat banyak untuk dieksploitasi dan diolah.

Mengingat semakin banyaknya produk Air Minum Dalam Kemasan (AMDK) yang diproduksi dalam wilayah pantai barat selatan Aceh dan semakin banyak pula masyarakat yang mengkonsumsinya serta besarnya dampak terhadap negatif terhadap kesehatan masyarakat akan kelebihan mineral, diantaranya $\mathrm{Pb}$ dan $\mathrm{Fe}$, telah menginspirasi peneliti untuk melakukan penelitian untuk menguji banyaknya kandungan $\mathrm{Pb}$ dan $\mathrm{Fe}$ yang terdapat pada Air Minum Dalam Kemasan (AMDK) beberapa produk lokal pantai barat dan selatan propinsi Aceh.

\section{METODE PENELITIAN}

Penelitian ini menggunakan metode deskriptif berdasarkan hasil uji laboratorium. Metode ini dilakukan dengan melihat gambaran dari analisis kandungan $\mathrm{Pb}$ dan $\mathrm{Fe}$ pada Air Minum Dalam Kemasan beberapa produk lokal pantai barat dan selatan propinsi Aceh. Penelitian dilakukan pada bulan November - Desember 2014.

Populasi penelitian ini adalah seluruh merek produk Air Minum Dalam Kemasan yang diproduksi dalam wilayah Pantai Barat Selatan Aceh sampai dengan akhir tahun 2014. Oleh karena jumlah seluruh merek Air Minum Dalam Kemasan yang diproduksi dalam wilayah Pantai Barat Selatan Aceh tidak sampai 100, maka seluruh merek Air Minum Dalam Kemasan akan dijadikan sampel. Adapun teknik pengambilan sampel dilakukan secara purposive sampling, dimana setiap merek diambil 3 (tiga) sampel air minum dalam kemasan gelas 220-230 ml dari pasar/tempat yang berbeda. Jika merek air minum dalam kemasan tersebut didistribusikan keluar kabupaten dari kabupaten asal merek air minum tersebut diproduksi, maka sampel akan diambil dari 3 kabupaten yang berbeda dan jika merek air minum tersebut tidak terdapat diluar kabupaten produksinya, maka sampel akan diambil dari 3 kecamatan yang berbeda.

Hasil observasi awal, peneliti mendapati 3 merek Air Minum Dalam Kemasan yang diproduksi dalam kabupaten Aceh Barat Daya (Abdya) dan mudah didapati sepanjang pantai Barat dan Selatan Aceh. Oleh karena itu, sampel untuk masing-masing merek tersebut diambil dari 3 kabupaten yang berbeda.

Selanjutnya ada 2 merek Air Minum Dalam Kemasanan yang diproduksi di kabupaten Aceh Singkil dan tidak didstribusikan keluar dari kabupaten tersebut. Hal ini juga terjadi di kabupaten Aceh Barat (1 merek) dan kabupaten Simeulu (1 merek) yang hanya diproduksi dan didistribusikan dalam wilayah tersebut saja. Sehingga sampel untuk 
masing-masing dari keempat merek Air Minum Dalam Kemasan tersebut diperoleh dari 3 kecamatan yang berbeda dari masing-masing kabupaten tersebut. Sehingga sampel berjumlah 21 sampel. Setiap sampel akan diuji kandungan $\mathrm{Pb}$ dan Fe. Setiap parameter yang diuji akan dilakukan 2 (dua) kali, sehingga jumlah keseluruhan sampel adalah 42 sampel dengan jumlah uji keseluruhan sebanyak 82 uji.

Dalam setiap sampel uji tidak ditunjukkan merek Air Minum Dalam Kemasan (AMDK) yang sedang diuji. Setiap merek diberi kode A, B, C, D, E, F dan G. Kemudian kode abjad tersebut ditambah notasi 1, 2 dan 3 yang menunjukkan tempat kesatu, tempat kedua dan tempat ketiga merek Air Minum Dalam Kemasan (AMDK) tersebut diperoleh. Selanjutnya ditambah kode R1 dan R2 yang menunjukkan pengulangan (replika) pengujian sampel uji.

\section{HASIL DAN PEMBAHASAN}

Hasil uji dari 42 sample disajikan dalam tabel 1. Tabel 1 memperlihatkan hasil yang sangat baik terhadap kandungan $\mathrm{Pb}$, dimana dari ketujuh merek AMDK tidak menunjukkan kandungan $\mathrm{Pb}$ sampai batas terendah yang mampu dideteksi oleh Spektrosfotometri Serapan Atom (SSA), yaitu $0,002 \mathrm{mg} / \mathrm{l}$. Kandungan $\mathrm{Pb}$ maksimum dalam air minum yang dizinkan sesuai Permenkes Nomor 492/2010, yaitu tidak melebihi $0,01 \mathrm{mg} / 1$.

Cemaran logam $\mathrm{Pb}$ dalam air minum pernah dilaporkan oleh Wiranti dkk, dimana terdapat tujuh dari sepuluh sampel air minum isi ulang di Purwokerto yang kadar kandungan $\mathrm{Pb}$ berada diatas batas maksimum yang ditetapkan SNI-01-3553-2006, yaitu $0,05 \mathrm{ppm}$. Sedangkan kadar $\mathrm{Pb}$ terendah dari hasil uji adalah 1,14 ppm dan kadar tertinggi adalah 17,5 ppm. Namun dalam laporan tersebut, Wiranti tidak menjelaskan lebih lanjut kapan penelitian dilakukan dan juga tidak ada keterangan media yang mengpublishkan laporannya [5].

Selanjutnya uji kandungan $\mathrm{Pb}$ dalam air baku juga pernah dilaporkan oleh Amiruddin dkk, dimana hasil penelitian menunjukkan bahwa air sungai Wonokromo Surabaya saat itu masih memenuhi kriteria kelas 1, yang berarti air sungai Wonokromo masih layak digunakan sebagai bahan baku air minum masyarakat Surabaya. Hal ini karena hasil uji kandungan $\mathrm{Pb}$ dalam air sungai tersebut masih dibawah syarat yang ditetapkan berdasarkan Keputusan Menteri Kesehatan Republik Indonesia Nomor 907/MENKES/SK/VII/2002 [6], yaitu sebesar 0,01 mg/l. Sedangkan hasil uji kandungan $\mathrm{Pb}$ air sungai Wonokromo hanya menunjukkan nilai terendah $0,0150 \mathrm{mg} / 1 \mathrm{dan}$ nilai tertinggi $0,0310 \mathrm{mg} / 1[7]$.

Selanjutnya hasil uji kandungan Fe pada 7 (tujuh) merek Air Minum Dalam Kemasan yang diuji dalam penelitian ini memberikan nilai yang bervariasi, akan tetapi kandungan tersebut masih sangat rendah dibandingkan kandungan Fe yang diizinkan sesuai Permenkes Nomor 492/2010, yaitu tidak melebihi 0,3 mg/l. Dimana ada 2 merek AMDK mempunyai kandungan $\mathrm{Fe}$ hampir mencapai $1,5 \mathrm{mg} / \mathrm{l}$, sedangkan dari 5 merek AMDK lainnya mempunyai kandungan Fe berkisar 0,0113 - 0,0941 mg/l. Penelitian kandunan Fe dalam air minum juga telah dilakukan oleh Kacaribu (2008). Kacaribu mengambil sampel air minum dari 3 (tiga) Depot Air Minum Isi Ulang di kota Medan dan diperoleh kandungan Fe rata-rata sebesar $0,0796 \mathrm{mg} / \mathrm{l}$. hasil penelitian tersebut menunjukkan bahwa ketiga Depot Air Minum Isi Ulang tersebut masih aman dikonsumsi masyarakat.

Tabel 1. Hasil Uji Kandungan Pb dan Fe dari 7 Merek AMDK 


\begin{tabular}{|c|c|c|c|c|}
\hline \multirow{2}{*}{ No. } & \multirow{2}{*}{$\begin{array}{c}\text { Sampel } \\
\text { ID }\end{array}$} & \multicolumn{3}{|c|}{ Hasil Analisa } \\
\hline & & Replika & $\begin{array}{c}\mathrm{Pb} \\
\mathrm{mg} / \mathrm{l}\end{array}$ & $\begin{array}{c}\mathrm{Fe} \\
\mathrm{mg} / \mathrm{l}\end{array}$ \\
\hline 1. & \multirow{2}{*}{ A 1} & $\mathrm{R}-1$ & $\leq 0,002$ & 0,0113 \\
\hline 2. & & $\mathrm{R}-2$ & $\leq 0,002$ & 0,0113 \\
\hline 3. & \multirow{2}{*}{ A 2} & $\mathrm{R}-1$ & $\leq 0,002$ & 0,0113 \\
\hline 4. & & $\mathrm{R}-2$ & $\leq 0,002$ & 0,0153 \\
\hline 5. & \multirow{2}{*}{ A 3} & $\mathrm{R}-1$ & $\leq 0,002$ & 0,0113 \\
\hline 6. & & $\mathrm{R}-2$ & $\leq 0,002$ & 0,0124 \\
\hline 7. & \multirow{2}{*}{ B 1} & $\mathrm{R}-1$ & $\leq 0,002$ & 0,0193 \\
\hline 8. & & $\mathrm{R}-2$ & $\leq 0,002$ & 0,0193 \\
\hline 9. & \multirow{2}{*}{ B 2} & $\mathrm{R}-1$ & $\leq 0,002$ & 0,0493 \\
\hline 10. & & $\mathrm{R}-2$ & $\leq 0,002$ & 0,0493 \\
\hline 11. & \multirow{2}{*}{ B 3} & $\mathrm{R}-1$ & $\leq 0,002$ & 0,0633 \\
\hline 12. & & $\mathrm{R}-2$ & $\leq 0,002$ & 0,0633 \\
\hline 13. & \multirow{2}{*}{ C 1} & $\mathrm{R}-1$ & $\leq 0,002$ & 0,0640 \\
\hline 14. & & $\mathrm{R}-2$ & $\leq 0,002$ & 0,0641 \\
\hline 15. & \multirow{2}{*}{ C 2} & $\mathrm{R}-1$ & $\leq 0,002$ & 0,0610 \\
\hline 16. & & $\mathrm{R}-2$ & $\leq 0,002$ & 0,0614 \\
\hline 17. & \multirow{2}{*}{ C 3} & $\mathrm{R}-1$ & $\leq 0,002$ & 0,0881 \\
\hline 18. & & $\mathrm{R}-2$ & $\leq 0,002$ & 0,0881 \\
\hline 19. & \multirow{2}{*}{ D 1} & $\mathrm{R}-1$ & $\leq 0,002$ & 0,0821 \\
\hline 20. & & $\mathrm{R}-2$ & $\leq 0,002$ & 0,0823 \\
\hline 21. & \multirow{2}{*}{ D 2} & $\mathrm{R}-1$ & $\leq 0,002$ & 0,0748 \\
\hline 22. & & $\mathrm{R}-2$ & $\leq 0,002$ & 0,0797 \\
\hline
\end{tabular}

\begin{tabular}{|c|c|c|c|c|}
\hline \multirow{2}{*}{ No. } & \multirow{2}{*}{$\begin{array}{c}\text { Sampel } \\
\text { ID }\end{array}$} & \multicolumn{3}{|c|}{ Hasil Analisa } \\
\hline & & Replika & $\begin{array}{c}\mathrm{Pb} \\
\mathrm{mg} / 1\end{array}$ & $\begin{array}{c}\mathrm{Fe} \\
\mathrm{mg} / 1\end{array}$ \\
\hline 23. & \multirow{2}{*}{ D 3} & $\mathrm{R}-1$ & $\leq 0,002$ & 0,0941 \\
\hline 24. & & $\mathrm{R}-2$ & $\leq 0,002$ & 0,0939 \\
\hline 25. & \multirow{2}{*}{ E 1} & R-1 & $\leq 0,002$ & 0,0338 \\
\hline 26. & & $\mathrm{R}-2$ & $\leq 0,002$ & 0,0336 \\
\hline 27. & \multirow{2}{*}{ E 2} & $\mathrm{R}-1$ & $\leq 0,002$ & 0,0290 \\
\hline 28. & & $\mathrm{R}-2$ & $\leq 0,002$ & 0,0295 \\
\hline 29. & \multirow{2}{*}{ E 3} & $\mathrm{R}-1$ & $\leq 0,002$ & 0,0291 \\
\hline 30. & & $\mathrm{R}-2$ & $\leq 0,002$ & 0,0290 \\
\hline 31. & \multirow{2}{*}{ F 1} & $\mathrm{R}-1$ & $\leq 0,002$ & 0,1642 \\
\hline 32. & & $\mathrm{R}-2$ & $\leq 0,002$ & 0,1641 \\
\hline 33. & \multirow{2}{*}{ F 2} & $\mathrm{R}-1$ & $\leq 0,002$ & 0,1452 \\
\hline 34. & & $\mathrm{R}-2$ & $\leq 0,002$ & 0,1457 \\
\hline 35. & \multirow{2}{*}{ F 3} & $\mathrm{R}-1$ & $\leq 0,002$ & 0,1260 \\
\hline 36. & & $\mathrm{R}-2$ & $\leq 0,002$ & 0,1258 \\
\hline 37. & \multirow{2}{*}{ G 1} & $\mathrm{R}-1$ & $\leq 0,002$ & 0,1424 \\
\hline 38. & & $\mathrm{R}-2$ & $\leq 0,002$ & 0,1428 \\
\hline 39. & \multirow{2}{*}{ G 2} & $\mathrm{R}-1$ & $\leq 0,002$ & 0,1678 \\
\hline 40. & & $\mathrm{R}-2$ & $\leq 0,002$ & 0,1672 \\
\hline 41. & \multirow{2}{*}{ G 3} & R-1 & $\leq 0,002$ & 0,1424 \\
\hline 42. & & R-2 & $\leq 0,002$ & 0,1448 \\
\hline
\end{tabular}

\section{KESIMPULAN}

Hasil penelitian menunjukkan bahwa dari 42 sampel uji memberikan hasil yang sangat baik terhadap kandungan $\mathrm{Pb}$, dimana dari ketujuh merek AMDK yang diuji tidak menunjukkan kandungan $\mathrm{Pb}$ sampai batas terendah yang mampu dideteksi oleh Spektrosfotometri Serapan Atom (SSA), yaitu $0,002 \mathrm{mg} / \mathrm{l}$. Kandungan $\mathrm{Pb}$ maksimum dalam air minum yang dizinkan sesuai Permenkes Nomor 492/2010, yaitu tidak melebihi 
0,01 mg/l. Sedangkan kandungan Fe pada 7 merek AMDK yang diuji memberikan nilai yang bervariasi, akan tetapi kandungan tersebut juga masih sangat rendah dibandingkan kandungan Fe yang diizinkan dalam Permenkes Nomor 492/2010, yaitu tidak melebihi 0,3 $\mathrm{mg} / \mathrm{l}$. Dimana ada 2 merek AMDK mempunyai kandungan Fe hampir mencapai 1,5 mg/l, sedangkan dari 5 merek AMDK lainnya mempunyai kandungan Fe berkisar 0,0113 $0,0941 \mathrm{mg} / \mathrm{l}$.

Jadi, dari hasil yang diperoleh tersebut dapat disimpulkan bahwa ketujuh merek Air Minum Dalam Kemasan (AMDK) produksi wilayah Pantai Barat Selatan Aceh adalah aman dikonsumsi masyarakat, karena tidak menimbulkan dampak dari kandungan $\mathrm{Pb}$ dan Fe yang masih jauh dari batas minimum yang diizinkan Permenkes Nomor 492/2010.

\section{SARAN}

Dalam rangka menyongsong dan menghadapi era globalisasi dan perdagangan bebas ASEAN dan dunia, maka pemerintah melalui Dinas Kesehatan Kabupaten dan Balai Pengawasan Obat dan Makanan (BPOM) harus serius dan terus menerus melakukan pengawasan dan pembinaan terhadap kualitas air minuman dalam kemasan produksi lokal agar mampu bersaing dengan produk sejenis lainnya baik ditingkat nasional maupun internasional.

\section{DAFTAR PUSTAKA}

[1] Sumantri. A. 2010. Kesehatan lingkungan. Jakarta: Kencana Prenada Media Grup.

[2] Kacaribu, 2008, Kandungan Kadar Seng (Zn) dan Besi (Fe) Dalam Air Minum Depot Air Minum isi Ulang Air Pegunungan Sibolangit di Kota Medan, Thesis, Universitas Sumatra Utara: Medan.

[3] Direktur Jenderal Industri Agro dan Kimia, 2007, Peraturan Direktur Jenderal Industri Agro dan Kimia Nomor 2/lak/Per/3/2007 Tentang Pedoman Pengawasan Penerapan SNI Air Minum Dalam Kemasan Di Pabrik, Jakarta: Dirjen Industri Agro dan Kimia.

[4] Widowati, W., Sastiono, A. dan Jusuf, R. R, 2008, Efek Toksik Logam Pencemaran dan Penanggulangan Pencemaran, Yogyakara: Andi offset.

[5] Wiranti S.R., Pri I.U., dan Yulike R.S., Identifikasi Cemaran Logam Timbal Dalam Air Minum Isi Ulang Yang Beredar di Purwokerto Dengan Metode Spektrofotometri Serapan Atom, Fakultas Farmasi Universitas Purwokerto, PO Box 202.

[6] Amiruddin P., Dewi M., dan Asri D., 2008, Kandungan Logam Berat Timbal (Pb), Kadmium (Cd) dan Tembaga (Cu) Dalam Air Kali Wonokromo, Majalah Farmasi Airlangga, Volume 6, Nomor 1, Surabaya.

[7] Menteri Kesehatan Republik Indonesia, 2010, Peraturan Menteri Kesehatan Republik Indonesia Nomor 492/Menkes/IV/2010 Tentang Persyaratan Air Minum, Jakarta: Kementerian Kesehatan Republik Indonesia. 